\title{
PENERAPAN BUKU AJAR NIHONGO KIRAKIRA OLEH GURU BAHASA JEPANG DI SMA NEGERI 4 SINGARAJA TAHUN AJARAN 2018/2019
}

\author{
N. N. Y.S . Mayanti ${ }^{1}$, K. E. K. Adnyani ${ }^{2}$, D.M. Mardani ${ }^{3}$ \\ ${ }^{123}$ Jurusan Pendidikan Bahasa Jepang, Universitas Pendidikan Ganesha, Singaraja \\ e-mail: mayantis59@gmail.com, krishna.adnyani@undiksha.ac.id, desak.mardani@undiksha.ac.id
}

\begin{abstract}
Abstrak
Penelitian ini bertujuan untuk menganalisis (1) penerapan buku ajar Nihongo Kirakira, (2) kendala penerapan buku ajar Nihongo Kirakira, serta (3) cara mengatasi kendala penerapan buku ajar Nihongo Kirakira oleh guru bahasa Jepang di SMA Negeri 4 Singaraja. Penelitian ini merupakan penelitian deskriptif kualitatif. Subjek penelitian ini yaitu salah satu guru bahasa Jepang di SMA Negeri 4 Singaraja. Metode pengumpulan data yang digunakan yaitu observasi, wawancara dan dokumentasi. Hasil penelitian ini menunjukkan (1) penerapan buku ajar Nihongo Kirakira oleh guru bahasa Jepang di SMA Negeri 4 Singaraja diterapkan sesuai pedoman penggunaan buku ajar Nihongo Kirakira dengan kegiatan mitekangaemashou, kiiteimashou, nihongo de iimashou, yomimashou, kakimashou, kikimashou, hanashimashou, roorupurei, proyek, refleksi materi pembelajaran, bunka, rangkuman materi pembelajaran, penilaian diri dan renshuu mondai. Media pembelajaran yang digunakan guru yaitu audio, power point dan LCD proyektor. (2) kendala yang dihadapi guru dalam penerapan buku ajar Nihongo Kirakira antara lain pada kegiatan pembelajaran kakimashou (siswa tidak menghafal huruf hiragana dan katakana), kegiatan kiite iimashou (audio tidak berbunyi), penggunaan media pembelajaran (LCD proyektor rusak), alokasi waktu yang kurang dan pengelolaan kelas (siswa ribut) serta (3) guru mengatasi kendala pembelajaran dengan cara memberi siswa latihan menulis ke depan, mendengarkan audio kiite iimashou yang sudah diunduh pada laman yang disediakan The Japan Foundatio, memindahkan tempat belajar ke kelas yang tersedia LCD proyektor yang tidak rusak, memilih beberapa kegiatan yang harus dilaksanakan, memberi teguran pada siswa yang ribut dan tidak menyimak penjelasan dengan baik.
\end{abstract}

Kata kunci: bahasa Jepang , kendala, Nihongo Kirakira, penerapan

要旨

本研究の目的は、(1)「日本語キラキラ」という教科書の適用について説明する、(2)

「日本語キラキラ」適用時の問題点について説明する、(3)シンガラジャ第四国立高 等学校の日本語教師が「日本語キラキラ」を適用する際、その問題点の解決方法に ついて分析を行う。本研究は定性的な記述的研究である。本研究の主題は、シンガ ラジャ第四国立高等学校の一人日本語の教師である。本研究の結果は以下の通りで ある。(1)シンガラジャ第四国立高等学校の日本語教師による「日本語キラキラ」の 適用は、その手引きに従って適用されている。手引きの構成は、「見て考えましょ う、聞いて言いましょう、日本語で言いましょう、読みましょう、書きましょう、 聞きましょう、話しましょう、ロールプレイ、宿題、復習、文化、まとめ、自己評 価、及び、練習問題」となっており、これに従いクラス活動が実施された。クラス 活動では、オーディオ、パワーポイント、LCDプロジェクターなどの学習メディア が使用された。(2)「日本語キラキラ」の適用において教師が直面している問題は、 書きましょうの活動をする際生徒が日本の文字を覚えない、聞いて言いましょうの 活動をする際オーディオの音声が出ない、学習道具の使用「LCDプロジェクターが 壊れた」、授業の時間配分が不足と授業管理「生徒が騒がしい」。(3)「日本語キラ キラ」の適用の問題点を解決するために、先生は生徒が筆記活動をするために前に 来るように求めた，「聞いて言いましょう」のオーディオをダウンロードし、それが 使用できるLCDのある教室に移動し、相当な活動を選択し、授業を聞かない学習者 に注意した。

キーワード：日本語、教科書の利用、「日本語キラキラ」、問題 


\section{Pendahuluan}

Kurikulum merupakan salah satu unsur yang memberikan kontribusi untuk mewujudkan proses perkembangan potensi peserta didik. Kurikulum 2013 dikembangkan berbasis pada kompetensi yang sangat diperlukan sebagai instrumen untuk mengarahkan peserta didik menjadi (1) manusia berkualitas yang mampu dan proaktif menjawab tantangan zaman yang selalu berubah; (2) manusia terdidik yang beriman dan bertakwa kepada Tuhan Yang Maha Esa, berakhlak mulia, sehat, berilmu, cakap, kreatif, mandiri, dan (3) warga negara yang demokratis serta bertanggung jawab. Dari tiga tujuan tersebut dapat disimpulkan aspek karakter religios, karakter sosial, pengetahuan dan keterampilan menjadi fokus dari kurikulum 2013 (Kemendikbud, 2014). Kurikulum 2013 menerapkan pendekatan belajar scientific. Pendekatan pembelajaran dilakukan melalui proses ilmiah. Pendekatan scientific adalah pendekatan pembelajaran yang dilakukan melalui proses mengamati, menanya, mencoba, menalar dan mengkomunikasi (Fadlillah, 2014: 175).

SMA Negeri 4 Singaraja merupakan salah satu sekolah yang sudah menerapkan kurikulum 2013. Berdasarkan kurikulum 2013, SMA Negeri 4 Singaraja merancang program pembelajaran yang dijadikan acuan pelaksanaan pembelajaran. SMA Negeri 4 Singaraja sendiri memiliki tenaga pengajar yang sudah memiliki pengalaman mengajar yang baik. Salah satunya yaitu pengajar yang menjadi subjek dalam penelitian ini, guru telah mengajar bahasa Jepang di SMA Negeri 4 Singaraja selama 15 tahun, dimulai dari tahun 2004 sampai sekarang tahun 2019. Guru bahasa Jepang yang menjadi subjek penelitian ini telah banyak melahirkan siswa yang berprestasi dibidang bahasa Jepang.

Pelaksanaan pembelajaran oleh guru dilaksanakan dengan semaksimal mungkin sesuai dengan model pembelajaran menggunakan pendekatan scientific. Berdasarkan observasi yang telah dilakukan, diketahui bahwa pembelajaran bahasa Jepang guru menggunakan buku ajar Nihongo Kirakira, dalam proses pembelajaran menggunakan buku ajar Nihongo Kirakira, terlihat proses pembelajaran bahasa Jepang di dalam kelas sangat aktif.

Alur pembelajaran dalam buku ajar Nihongo Kirakira menerapkan pendekatan saintifik, serta mempergunakan berbagai metode dan strategi sesuai dengan pembelajaran yang memperhatikan kompetensi sikap, pengetahuan dan keterampilan (Lusiana dkk, 2017). Buku ajar Nihongo Kirakira ini dilengkapi dengan media pembelajaran seperti audio dan power point yang dapat digunakan oleh guru untuk mempermudah proses pembelajaran. Selain itu The Japan Foundation juga meyusun buku Nihongo Kirakira khusus digunakan oleh guru yang berisi panduan penggunaan buku dari buku ajar Nihongo Kirakira untuk kelas X sampai kelas XII.

Berdasarkan hasil observasi dan wawancara tersebut penelitian ini dilaksanakan untuk mengetahui penerapan buku ajar Nihongo Kirakira oleh guru bahasa Jepang di SMA Negeri 4 Singaraja. Hasil dari penelitian ini nantinya dapat dijadikan sebagai tambahan informasi bagi guru dalam penerapan buku ajar Nihongo Kirakira serta dapat dijadikan pedoman oleh mahasiswa jurusan pendidikan bahasa Jepang yang nantinya akan melaksanakan PPL-Real di sekolah menengah atas dengan menggunakan buku ajar Nihongo Kirakira pada pembelajaran bahasa Jepang.

Penelitian tentang buku ajar Nihongo Kirakira sudah pernah dilaksanakan pada tahun 2017 di Singaraja dan tahun 2018 di Mojokerto. Penelitian yang pertama yang dilakukan oleh Megantara (2017) dirancang dalam bentuk deskriptif-kualitatif. Subjek dari penelitian tersebut yaitu guru bahasa Jepang di SMA Negeri 3 Singaraja. Sedangkan objek dari penelitian tersebut yaitu penggunaan buku ajar Nihongo Kirakira berbasis kurikulum 2013. Penelitian tersebut menggambarkan bahwa guru mengalami kendala dalam penggunaan buku ajar Nihongo Kirakira berbasis kurikulum 2013. Persamaan penelitian tersebut dengan penelitian ini yaitu sama-sama meneliti mengenai penggunaan buku ajar Nihongo Kirakira. Perbedaannya yaitu penelitian sebelumnya dilakukan di SMA Negeri 3 Singaraja dengan fokus penelitian mengenai penerapan 5M (mengamati, menanya, mengumpulkan informasi, mengasosiasi dan mengkomunikasi) pada penerapan buku ajar Nihongo Kirakira. Sedangkan dalam penelitian ini fokus penelitian pada penerapan buku ajar Nihongo Kirakira, serta kendala dan cara guru mengatasi kendala yang ada.

Penelitian kedua yang dilakukan oleh Lusfita (2018) dirancang dalam bentuk deskriptif kuantitatif. Subjek dari penelitian tersebut yaitu siswa kelas XI Bahasa MA Negeri 1 Mojokerto. Sedangkang objek dari penelitian tersebut yaitu kemampuan berbicara bahasa 
Jepang melalui teknik role play dalam buku ajar Nihongo Kirakira.penelitian tersebut menggambarkan bahwa kemampuan berbicara bahasa Jepang siswa kelas XI MA Negeri 1 Mojokerto termasuk dalam kategori B serta siswa sulit untuk membuat percakapan (secara tertulis) dalam bahasa Jepang. namun siswa tidak mengalami kesulitan untuk berdialog dengan temannya di depan kelas. Perbedaannya adalah penelitian yang dilakukan oleh Lusfita (2018) subjek dari penelitian ini yaitu siswa kelas XI Bahasa yang dilaksanakan di MA Negeri 1 Mojokerto, sedangkan subjek dari penelitian ini yaitu guru bahasa Jepang di SMA Negeri 4 Singaraja.

Berdasarkan latar belakang tersebut, adapun rumusan masalah yang dapat dirumuskan adalah sebagai berikut:

1) Bagaimanakah penerapan buku ajar Nihongo Kirakira oleh guru bahasa Jepang di SMA Negeri 4 Singaraja?

2) Bagaimanakah kendala penerapan buku ajar Nihongo Kirakira oleh guru bahasa Jepang di SMA Negeri 4 Singaraja?

3) Bagaimanakah cara mengatasi kendala penerapan buku ajar Nihongo Kirakira oleh guru bahasa Jepang di SMA Negeri 4 Singaraja?

\section{Metode}

Penelitian deskriptif kualitatif ini dilaksanakan di SMA Negeri 4 Singaraja pada kelas X BB dan XI BB tahun ajaran 2018/2019. Subjek yang digunakan pada penelitian ini adalah guru bahasa Jepang di SMA Negeri 4 Singaraja. Sedangkan objek dari penelitian ini adalah penerapan buku ajar Nihongo Kirakira, kendala penerapan buku ajar Nihongo Kirakira dan cara mengatasi kendala dalam penerepan buku ajar Nihongo Kirakira.

Metode pengumpulan data pada penelitian ini menggunakan metode observasi, wawancara dan dokumentasi. Observasi dilaksanakan sebanyak 8 (delapan) kali pada kelas X BB 1, X BB 2, XI BB 1 dan XI BB 2. Model wawancara yang akan digunakan yaitu wawancara semi terstruktur dengan responden pada wawancara ini yaitu guru bahasa Jepang di SMA Negeri 4 Singaraja yang bernama Drs. Nyoman Mangku Mariada. Wawancara dilaksanakan sebanyak dua kali. Wawancara pertama digunakan untuk mencari informasil awal mengenai penerapan buku ajar Nihongo Kirakira, sedangkan wawancara kedua digunakan untuk mencari informasi mendalam mengenai penerapan buku ajar Nihongo Kirakira di SMA Negeri 4 Singaraja. Kemudian metode dokumentasi digunakan untuk mendokumentasikan foto-foto proses pembelajaran bahasa Jepang dari awal pembelajaran sampai akhir.

Teknik analisis data yang digunakan adalah metode analisis deskriptif kualitatif yaitu suatu cara pengelolahan data yang dilakukan dengan cara menyusun data secara sistematik sehingga diperoleh suatu simpulan umum. Prosedur yang ditempuh dalam menganalisis data pada penelitian ini yakni (1) tabulasi data, (2) reduksi data, (3) deskripsi data, (4) klasifikasi data, (5) penarikan kesimpulan.

\section{Hasil dan Pembahasan}

Pengambilan data dengan cara observasi dilakukan di 4 (empat) kelas yang berbeda yaitu kelas X BB 1, X BB 2, XI BB 1 dan XI BB 2. Adapun hasil observasi dari masing-masing kelas akan dipaparkan sebagai berikut.

\section{Hasil Observasi Kelas X BB 1}

Pelaksanaan observasi pada kelas X BB 1 dilakukan pada hari Rabu tanggal 10 dan Senin tanggal 15 April 2019. Jadwal pelajaran bahasa Jepang di kelas X BB 1 hari Rabu yaitu jam 07.15 - 08.45 Wita, kemudian jam 12.00 - 12.45 Wita pada hari Senin. Kemudian pelaksanaan observasi pada kelas X BB 2 dilakukan pada hari Senin 15 \& Kamis 18 April 2019. Jadwal pelajaran bahasa Jepang di kelas X BB 2 hari Senin yaitu jam $14.00-1.30$ Wita, kemudian jam 07.15 - 08.00 Wita pada hari Kamis.

Sebelum memulai pembelajaran Nihongo Kirakkira bab 11 (すいようびにバティックをきます) “suiyoubi ni batikku wo kimasu” terlebih dahulu guru mengulang pembahasan mengenai bab sebelumnya. Kegiatan mitekangaemashou Jurnal Pendidikan Bahasa Jepang | 75 
dilaksanakan guru dengan meminta siswa untuk mengamati gambar dan menganalisis gambar. Guru menanyakan gambar-gambar tersebut tentang apa, kemudian seluruh siswa menjawab bahwa gambar tersebut tentang pakaian seragam yang digunakan oleh siswa Jepang dan siswa Indonesia.

Pelaksanaan kegiatan kiiteimashou, guru memperkenalkan kosakata baru dan pola kalimat dengan terlebih dahulu melakukan latihan yang ada pada kegiatan kite iimashou. Kemudian pada kegiatan nihongo de iimashou Guru menampilkan kalimat tanya bahasa Indonesia satu persatu, kemudian meminta siswa untuk menebak jawaban dari pertanyaan tersebut, jawaban disampaikan menggunakan bahasa Jepang dengan menggunakan pola kalimat yang sudah dipelajari.

Selanjutnya guru melanjutkan pada kegiatan yomimashou. Kegiatan ini dilaksanakan sebanyak dua kali, yang pertama siswa diminta untuk menjodohkan kosakata, kedua siswa diminta untuk mencari nama-nama hari dalam tulisan Jepang baik horizontal, vertikal maupun diagonal pada lembar kerja 2. Setelah selesai kegiatan yomimashou guru melaksanakan kegiatan kakimashou. Kegiatan ini diberikan guru untuk melatih huruf Jepang siswa. latihan diberikan sesuai dengan latihan yang ada dalam buku ajar Nihongo Kirakira.

Pada kegiatan kikimashou siswa diminta memperdengarkan percakapan pada audio, kemudian mencari jawaban soal dari percakapan yang diperdengarkan guru. Guru menampilkan latihan kikimashou kemudian meminta siswa untuk memperhatikan latihan pada buku yang jawabannya harus dicocokkan dengan apa yang siswa dengar. Setelah kegiatan ini selesai dilanjudkan dengan kegiatan hanashimashou dimana pada kegiatan ini guru melatih siswa untuk membuat percakapan bahasa Jepang. percakapan yang sudah dibuat siswa secara berpasangan kemudian dipraktekkan pada kegiatan roorupurei. Setelah satu materi selesai dibahas guru selanjudnya guru melakukan refleksi materi pembelajaran.

Setelah melakukan refleksi pembelajaran guru melaksanakan kegiatan bunka. Pada kegiatan ini guru meminta siswa untuk mencari perbedaan pelajar yang menggunakan pakaian seragam dan tidak menggunakan pakaian seragam. Ketika kegiatan bunka berakhir guru melakukan penutupan pelajaran dengan terlebi dahulu melaksanakan rangkuman pembelajaran dan memberikan siswa tugas yang ada pada lembar renshuu mondai.

\section{Hasil Observasi Kelas XI}

Pelaksanaan observasi pada kelas XI BB 1 dilakukan pada hari Senin 22 tanggal dan Rabu tanggal 24 April 2019. Jadwal pelajaran bahasa Jepang di kelas XI BB 1 hari Senin yaitu pada jam 10.30 - 12.45 Wita, kemudian jam 10. 30 - 12. 45 Wita pada hari Rabu. Untuk kelas XI, jadwal pelajaran bahasa Jepang yaitu selama 4 (empat) jam dalam satu minggu. Sedangkan untuk pelaksanaan observasi pada kelas XI BB 2 dilakukan pada hari Rabu 24 \& kamis 25 April 2019. Jadwal pelajaran bahasa Jepang di kelas XI BB 2 hari Rabu yaitu jam 12.00 - 13.30 Wita, kemudian jam 12. 00 - 13. 30 Wita pada hari Kamis

Sebelum memulai pelajaran mengenai bab 23 (おかさんはジーンズをはいています。) "okasan ha jiinzu wo haite imasu) terlebih dahulu guru membahas tuga dokkai siswa dan melakukan latihan membaca kalimat bahasa Jepang. selanjutnya guru memulai kegiatan mitekangaemasou dengan menampilkan dua foto, guru meminta siswa untuk mengamati foto yang ditampilkan pada power point. Guru menampilkan dua foto dan meminta siswa mendiskusikan mengenai perbedaan dari kedua foto, bagaimana perbedaan penampilan orang-orang yg sedang menggunakan pakaian sehari-hari dan pakaian pesta. Setelah pembahasan pada kegiatan mitekangaemashou selesai guru melanjutkan pada kegiatan kiiteimashou.

Kegiatan kiiteimashou dilaksanakan guru untuk memperkenalkan kosakata dengan menampilkan gambar dan memperdengarkan cara pengucapan menggunakan audio. Terlebih dahulu siswa diminta untuk mendengarkan kemudian mengucapkan secara bersamaan-sama, begitu seterusnya sampai seluruh kosakata habis, namun pada kosakata tambahan guru mengucapkan sendiri tanpa menggunakan audio kemudian siswa mengikuti. Selain memperkenalkan kosakata baru guru juga menjelaskan bentuk ujaran-ujaran yang dipelajari pada bab 23. Setelah selesai menjelaskan pola kalimat guru melanjutkan pada kegiatan nihongo de iimashou. Pada kegiatan ini guru menampilkan kalimat tanya bahasa Indonesia satu persatu, kemudian meminta siswa untuk menebak jawaban dari pertanyaan tersebut, jawaban disampaikan menggunakan bahasa Jepang dengan menggunakan pola 
kalimat yang sudah dipelajari.

Selanjudnya guru melanjudkan pada kegiatan yomimashou. guru memberikan latihan membaca yang ada pada langka yomimashou (latihan membaca). Pada latihan ini, guru meminta siswa memperhatikan latihan membaca pada halaman 165, siswa harus memperhatikan gambar apa saja yang terdapat pada latihan dan mencari serta melingkari nama dari gambar-gambar yang ada menggunakan pensil. Kemudian setelah selesai melakukan latihan membaca siswa melanjudkan pelajaran pada kegiatan menulis kakimashou.pelaksanaan latihan menulis ini, guru meminta siswa mengisi kolom yang kosong sesuai jawaban yang benar. Guru membuat sendiri soal untuk memudahkan siswa memahami soal yang diberikan guru, namun soal tersebut masih berkaitan dengan materi yang sedang dipeajari siswa. Guru mempersilahkan siswa untuk menjawab sambil berdiskusi dengan teman sebangku maupun teman yang ada di depan dan dibelakangnya.

Pada kegiatan kikimashou guru menampilkan latihan kikimashou kemudian meminta siswa untuk memperhatikan latihan pada buku yang jawabannya harus dicocokkan dengan apa yang siswa dengar. Guru memperdengarkan satu-persatu audio kemudian menanyakan pada siswa apakah sudah menemukan jawaban, terdapat siwa yang mengatakan belum, kemudian guru memperdengarkan kembali, beberapa kali sampai siswa selesai menjawab. Setelah selesai menjawab, guru dan siswa mengecek jawaban bersama-sama, siswa yang salah diminta guru untuk memperbaiki jawaban mereka. Pelaksanaan hanashimashou dilaksanakan setelah kegiatan kikimashou selesai. Pada kegiatan ini, terlebih dahulu guru menampilkan contoh percakapan, kemudian memperdengarkan contoh percakapan tersebut menggunakan audio. Guru menjelaskan mengenai contoh percaakapan serta meminta siswa untuk mengucapkan contoh percakapan yang ditampilkan pada power point, percakapan tersebut membahas mengenai salah satu keluarga yang mengenakan pakaian pada sebuah foto. Guru bertanya kepada siswa, apa arti dari percakapan tersebut, kemudian siswa menjawab dengan menterjemahkan percakapan kedalam bahasa Indonesia. Pada latihan berbicara ini guru meminta siswa untuk membuat percakapan seperti pada contoh bersama teman satu bangku. Guru memberi waktu kepada siswa untuk membuat percakapan. Hasil dari percakapan yang dibuat siswa pada kegiatan hanashimashou kemudian dipraktekkan siswa pada kegiatan roorupurei. Siswa maju untuk melakukan percakapan didepan diberikan nilai oleh guru untuk merangsang keinginan siswa untuk aktif melakukan praktek percakapan.

Setelah siswa selesai melakukan praktek berbicara, guru melanjudkan pada kegiatan proyek. Pada kegiatan ini siswa diminta untuk berkelompok dan membuat satu gambar pesta. Hasil gambar yang yang paling bagus akan dipilih siswa. kemudian kelompok dengan gambar yang paling bagus akan mempresentasikan hasil gambar mereka. presentasi yang dilakukan menggunakan bahasa Jepang. setelah siswa selesai melakukan presentasi, guru elanjutkan dengan melakukan refleksi materi pembelajaran. Guru menampilkan beberapa pola kalimat dan percakapan pada pola kalimat siswa diminta untuk menyebutkan fungsi dari setiap pola kalimat tersebut. Sedangkang pada percakapan, siswa diminta mencari perbedaan dari salah satu kata yang digunakan pada percakapan tersebut. Guru menyebut nama siswa secara acak, kemudian meminta siswa untuk menyebutkan fungsi kalimat dan perbedaan penggunaan kata yang ditampilkan guru pada power point. Satu persatu siswa memberikan jawaban mereka saat dipanggil guru.

Guru memperkenalkan kebudayaan Jepang kepada siswa dengan menampilkan dua gambar. Gambar tersebut kemudian diminta guru untuk dianalisis dan menjawab pertanyaan-pertanyaan yang ada pada buku ajar Nihongo Kirakira. Guru membentuk beberapa kelompok pada kegiatan bunka dan memerikan waktu siswa untuk menjawab semua pertanyaan pada lembar Bunka. Selanjudnya sebelum mengakhiri pelajaran guru melaksanakan rangkuman materi pembelajaran. Guru meminta siswa untuk menyimpulkan materi apa saja yang sudah dipelajari. Kemudian guru menunjuk siswa satu persatu secara acak untuk menyampaikan materi yang sudah dipelajari.

Setelah melaksanakan rangkuman guru meminta siswa mengisi kolom penilaian diri pada halaman 177. Hasil penilaian diri siswa rata-rata A dan B. Guru menyimpulkan bahwa siswa sudah memahami materi pembelajaran dengan baik. selanjudnya guru memberikan tugas kepada siswa untuk dikerjakan di rumah pada lembar renshuu mondai. 


\section{Pembahasan \\ Penerapan buku ajar Nihongo Kirakira \\ みてかんがえましょう (Mitekangaemashou)}

Tujuan dari kegiatan ini adalah untuk mengarahkan pemikiran siswa pada proses mengamati tema bab yang dipelajari dalam bab tersebut, serta memberikan gambaran target dari tema (Lusiana dkk, 2017). Pada tahap ini guru menampilkan tema pembelajaran dan gambar pada kegiatan Mitekangaemashou. Guru juga menambahkan beberapa gambar pada kegiatan ini untuk memberikan gambaran mengenai target dari tema pembelajaran kepada siswa.

Kegiatan pembelajaran pada kegiatan ini yaitu guru mengarahkan siswa untuk mengamati foto, kemudian menyatakan hal yang ada dalam masing-masing foto. Guru meminta siswa untuk mengamati gambar dan membuat siswa fokus dengan memberikan pertanyaan. Siswa diminta menjelaskan gambar tersebut mengenai apa dan perbedaan dari dua gambar yang ditampilkan guru. Hal ini sesuai dengan pedoman penggunaan buku ajar Nihongo Kirakira yaitu guru membantu dengan pertanyaan yang membuat siswa fokus pada hal yang perlu diamati pada tema tersebut. Contoh pertanyaan yaitu: apa, dimana, sedang apa, siapa, persamaan dan perbedaan dsb (Lusiana dkk, 2017).

\section{きいていましょう (Kiiteimashou)}

Tujuan kegiatan ini yaitu untuk mengenalkan arti, lafal kata, serta ungkapan yang digunakan dalam bab yang sedang dipelajari. Bagian ini juga menyediakan gambar situasi, audio dan tulisan dari kosakata yang diperkenalkan. Gambar dan foto membantu siswa memahami arti atau ungkapan audio untuk memberikan contoh pengucapan lafal yang baik. Sedangkan tulisan huruf Jepang untuk memperkenalkan kata-kata tersebut dalam huruf Jepang (Lusiana dkk, 2017).

Pada kegiata Kiiteimashou guru memberikan kosakata dan pola kalimat baru atau ungkapan-ungkapan yang akan digunakan siswa pada bab yang sedang dipelajari. Guru memperdengarkan audio dari kosakata dan pola kalimat. Guru meminta siswa menyimak kemudian mencocokkan jawab pada buku dengan apa yang didengarkan pada audio. Kegiatan Kiiteimashou yang dilaksanakan guru ini sesuai dengan kegiatan pembelajaran Nihongo Kirakira pada kegiatan Kiiteimashou yaitu siswa menyimak audio saja, kemudian siswa menyebutkan bahasa Jepang dari gambar yang ditunjuk/disebut nomornya oleh guru atau siswa lain, serta siswa mengerjakan tugas pencocokan tulisan dan gambar di buku, kemudian siswa saling mencocokkan dengan teman di dekatnya. Setelah siswa selesai mencocok kan dilanjudkan dengan memperdengarkan sekali lagi audio dan mencocokkan jawaban bersama-sama (Lusiana dkk, 2017).

\section{にほんごでいいましょう (Nihongo De limashou)}

Tujuan kegiatan Nihongo De limashou adalah banyak melatih penyebutan kata bahasa Jepang yang telah dipelajari di bagian sebelumnya dengan benar dan sesuai. Latihan ini adalah latihan menyebutkan kata dalam bahasa Jepang yang sesuai dengan mengasosiasi kata arahan dalam bahasa Indonesia agar siswa terbiasa mengemukakan pendapat. Sebelum memulai kegiatan ini guru terlebih dahulu menampilkan pertanyaan satu persatu, kemudian meminta siswa untuk menebak jawaban dari pertanyaan tersebut, jawaban disampaikan menggunakan bahasa Jepang dengan menggunakan pola kalimat yang sudah dipelajari. Jawaban yang diberikan siswa tidak selalu sama sesuai dengan sudat pandang siswa, contohnya ketika guru memberi pertanyaan mengenai "pakaian yang disuka" jawaban siswa pun berbeda-beda, ada yang menjawab「バリのふく」 "bari no fuku" (baju bali), ada juga yang menjawab「スポーツのせいふく」 "supottsu no seifuku" (seragam olahraga). Pelaksanaan ini sesuai dengan pendapat Lusiana dkk (2017) guru tidak menyalahkan jawaban siswa pada kegiatan Nihongo De limashou, karena tujuan kegiatan ini yaitu menyebutkan kalimat atau kosakata bahasa Jepang dan melatih siswa untuk berargumen atau mengemukakan pendapat. 


\section{よみましょう (Yomimashou)}

Guru pada penerapan よみましょう (Yomimashou) memberikan latihan menjodohkan antara tulisan dengan gambar dan menandai tulisan sesuai dengan kata-kata yang ditampilkan melalui gambar pada kotak huruf yang disediakan (Cross word). Kedua latihan yomimashou ini sesuai dengan tipe latihan yang disebutkan oleh Lusiana dkk (2017) yaitu bentuk latihan よみましょう (Yomimashou) ada beberapa tipe, ada menjodohkan antara tulisan dengan gambar atau mengisi jadwal, menandai tulisan sesuai dengan kata-kata yang ditampilkan melalui gambar pada kotak huruf yang disediakan (Cross word), membaca untuk memilih salah satu kata yang tak sesuai dan kegiatan membaca mengerjakan tugas.

Setiap tipe latihan pada kegiatan よみましょう (Yomimashou) ini disesuaikan dengan tema pembelajaran, sehingga pada setiap bab hanya terdapat salah satu atau dua dari tipe yang ada.Pelaksanaan kegiatan ini dilaksanakan guru dengan terlebih dahulu memberi waktu kepada siswa untuk menjodohkan, kemudian setelah dirasa siswa selesai menjawab latihan guru memanggil siswa untuk menjawab latihan secara satu persatu. Jika terdapat siswa salah menjawab akan diminta untuk memperbaiki jawaban sesuai dengan jawaban benar.

\section{かきましょう (Kakimashou)}

kakimashou merupakah kegiatan pembelajaran yang digunakan guru untuk melatih siswa menulis menggunakan huruf Jepang baik Hiragana maupun Katakan. Pada latihan ini guru sedikit merubah latihan yang ada pada buku agar latihan mudah dipahami oleh siswa, namun soal dari latihan tersebut tetap berasal dari buku ajar Nihongo Kirakira yang sesuai dengan materi pada bab yang sedang dipelajari. Guru juga memberikan contoh cara menjawab soal latihan yang tidak ada pada buku ajar Nihongo Kirakira. Tujuan kegiatan yang diberikan oleh guru ini sesuai dengan penyataan yang disampaikan oleh Lusiana dkk (2017) yaitu tujuan dari kegiatan kakimashou adalah untuk membuat siswa berlatih menulis menggunakan huruf Jepang.

\section{ききましょう (Kikimashou)}

Tujuan kegiatan ini adalah mengenalkan percakapan singkat sesuai tema, melalui tugas menyimak informasi tertentu. Percakapan tersebut menjadi model pada kegiatan output percakapan (Lusiana dkk, 2017). Guru melatih kemampuan mendengar bahasa Jepang siswa dengan memberi siswa latihan mendengarkan percakapan pada kegiatan

「ききましょう」 “kikimashou”. Guru menampilkan latihan「ききましょう」"kikimashou” kemudian meminta siswa untuk memperhatikan latihan pada buku yang jawabannya harus dicocokkan dengan percakapan yang didengar siswa pada audio. Setelah selesai menjawab, guru dan siswa mengecek jawaban bersama-sama, siswa yang salah diminta guru untuk memperbaiki jawaban mereka. Selanjutnya guru memperdengarkan kembali audio untuk siswa agar siswa dapat menangkap variasi percakapan seperti pertanyaan, jawaban dan lainnya. Kegiatan yang dilaksanakan guru sesuai dengan kegiatan pembelajaran ききましょう (Kikimashou) yaitu bila tidak ada kesalahan, gunakan audio untuk melatih siswa mendengarkan kembali, dan menangkap variasi percakapan (pertanyaan, jawaban, tanggapan dll) (Lusiana dkk, 2017).

\section{はなしましょう (Hanashimashou)}

Pada kegiatan ini siswa diberi kesempatan untuk berlatih melakukan percakapan. Sebelum melakukan latihan percakapan terlebih dahulu guru memperdengarkan contoh percakapan menggunakan audio. Kemudian meminta siswa mengulagi percakapan tersebut. Siswa diminta berpasangan membuat percakapan sesuai contoh yang diberikan dengan menyampaikan informasi yang sebenarnya. Melakukan percakapan dengan menyampaikan informasi sesuai dengan kenyataan ini sesuai dengan tujuan kegiatan Hanashimashou yaitu untuk memperkenalkan bentuk percakapan yang akan dilatihkan, bukan menghafal model percakapan. Siswa mengganti informasi tertentu dengan informasi yang sesuai dengan kondisi diri sendiri (otentik) (Lusiana dkk, 2017). 


\section{ロールプレイ (roorupurei)}

Kegiatan ini adalah kegiatan "outpuf", digunakan untuk memberikan kesempatan kepada siswa mempraktikkan kemampuan yang telah dilatihkan sebelumnya dengan situasi yang lebih nyata. Pelaksanaan kegiatan ini oleh guru memberikan kesempatan pada siswa untuk melakukan role play di depan kelas. Untuk memancing keinginan siswa melakukan role play guru menyampaikan bahwa siswa yang mau maju kedepan akan mendapatkan nilai tambahan sehingga siswa bersemangat ingin maju. Siswa maju kedepan melakukan percakapan secara bergiliran bersama pasangan mereka. Pada kegiatan pembelajaran

「ロールプレイ」 “roorupurei”, siswa secara bergiliran memberi pertanyaan dan merespons pertanyaan secara bergantian. Pada saat maju siswa tidak membawa catatan, namun siswa diharuskan melakukan percakapan sederhana menggunakan bahasa Jepang. penemuan ini sesuai dengan Lusiana dkk (2017) yaitu pada kegiatan ini yang dipentingkan bukan menghafal percakapan, namun dapat menanggapi percakapan sederhana sesuai situasi.

\section{Proyek}

Kegiatan ini merupakan kegiatan "output" dalam bentuk proyek, antara lain survei, pembuatan produk (kartu nama, poster, pamflet, jadwal dsb) sesuai tema dan target.

Pelaksanaan proyek dilakukan guru dengan meminta siswa untuk berkelompok kemudian setiap kelompok membuat gambar baju pesta. Kelompok-kelompok yang dibuat guru ini memberikan kesempatan siswa untuk melakukan kerjasama dengan teman. Hal ini sesuai dengan Lusiana dkk, (2017) yang menyatakan kegiatan proyek ini bertujuan untuk membangun sikap kerjasama, saling menghargai pendapat, kepemimpinan, ketelitian, disiplin terhadap waktu kerja, keberanian dalam berpresentasi.

Selanjutnya salah satu siswa melakukan presentasi mengenai baju pesta yang siswa buat. Sebelum presentasi guru sebelumnya sudah memberikan contoh presentasi dalam bentuk bahasa Jepang yang bisa diikuti siswa. siswa mempresentasikan hasil kerja kelompoknya di depan kelas. Dalam kegiatan proyek yang dilaksanakaan guru di dalam kelas sesuai dengan kegiatan kegiatan proyek Nihongo Kirakira oleh Lusiana dkk, (2017) yaitu Pelaksanaan proyek menggunakan bahasa Jepang sederhana dan terbatas. Pada sebagian proyek, siswa cukup menyalin frase atau kalimat bahasa Jepang yang disediakan guru. Bahasa Indonesia atau bahasa asing lainnya juga bisa dipakai untuk melengkapi.

\section{Refleksi Materi Pembelajaran}

Kegiatan ini digunakan untuk menyimpulkan materi pembelajaran sampai satu materi pada bab selesai dibahas. Refleksi dilaksanakan guru sebanyak satu atau dua kali tergantung pada banyaknya materi bada bab yang sedang dipelajari

Guru pada kegiatan refleksi ini tidak menjelaskan kembali mengenai setiap kosakata dan ujaran yang ditampilkan pada slide, guru hanya meminta siswa untuk memikirkan jawaban dari pertanyaan yang ditampilkan guru. Cara guru melaksanakan refleksi materi pembelajaran ini sesuai dengan pedoman pengguaan buku ajar Nihongo Kirakira ole Lusiana dkk, (2017) yaitu guru tidak menjelaskan apa-apa namun memberikan arahan agar siswa dapat fokus pada hal yang harus diperhatikan, serta mengapresiasi hasil pengamatan siswa yang tepat.

\section{ぶんか (Bunka)}

Kegiatan ini memberikan berkesempatan pada siswa untuk mengenal budaya Jepang. Namun, pengenalan budaya tidak berupa penjelasan, melainkan berupa pertanyaan yang membuat siswa dapat melakukan refleksi terhadap budaya sendiri. pada kegiatan ini guru menampilkan dua gambar dan beberapa peranyaan. Guru meminta siswa untuk membuat kelompok kecil, kemudian mendiskusikan mengenai jawaban dari soal-soal pada kegiatan bunka. Setelah selesai berdiskusi, guru meminta siswa untuk menjawab pertanyaan satu persatu.

Menurut Lusiana dkk (2017) kegiatan bunka ini diharapkan siswa terlatih belajar menilai poin-poin positif yang dimiliki budaya Jepang yang kemudian diadopsi menjadi budaya Indonesia. Selain itu, melalui pengetahuan tentang budaya Jepang, siswa diharapkan sadar akan kelebihan yang dimiliki oleh budaya Indonesia. Sesuai dengan pedoman penggunaan buku ajar Nihongo Kirakira pada kegiatan bunka guru merangsang pemikiran siswa Jurnal Pendidikan Bahasa Jepang | 80 
mengenai point-point positif pada budaya Jepang seperti budaya disiplin, tepat waktu dan lainnya namun juga bangga dengan kebudayaan Indonesia.

\section{Rangkuman Materi Pembelajaran}

Kegiatan ini adalah kegiatan siswa merangkum seluruh materi pembelajaran pada bab yang sedang dipelajari. Pelaksanaan kegiatan ini dilakukan diakir pelajaran yang bertujuan untuk merangkum materi pelajaran yang sudah dipelajari siswa. guru meminta siswa untuk menyimpulkan materi apa saja yang sudah dipelajari. Guru dapat menyebutkan mengenai kosakata, pola kalimat atau ujaran yang sudah dipelajari. Siswa juga dapat menyampaikan ontoh percakapan yang sudah dipelajari. Sesuai dengan kegiatan kegiatan rangkuman materi pembelajaran menurut Lusiana dkk (2017) pada kegiatan ini diharapkan siswa sendiri yang aktif menyimpulkan, guru hanya memberikan arahan apabila siswa kurang mampu merangkum simpulan, serta memberikan apresiasi kepada siswa yang berhasil membuat rangkuman yang sesuai.

\section{Penilaian Diri}

Kegiatan ini digunakan siswa untuk menilai pencapaian pembelajaran yang telah dilalui siswa yang dilakukan sendiri oleh siswa. Hasil dari penilaian diri ini nantinya akan digunakan guru sebagai pertimbangan mengenai keberhasilan atau kekurangan dari proses pembelajaran yang sudah berjalan. Menurut Lusiana dkk, (2017) hasil penilaian diri ini juga digunakan guru untu mencari solusi dari permasalahan siswa mengenai materi ajar jika terdapat siswa yang merasa dirinya kurang memahami materi ajar.

\section{れんしゅうもんだ (Renshuu Mondai)}

Pada kegiatan renshuu mondai mondai guru memberikan soal-soal yang berkaitan dengan materi ajar yang dipelajari pada bab yang dijadikan sebagai tugas untuk siswa. buku ajar Nihongo Kirakira menyediakan beberapa soal latihan yang dapat digunakan sebagai tugas oleh guru pada setiap akhir bab. Tugas dikumpulkan pada minggu selanjutnya untuk dinilai guru dan digunakan sebagai bahan evaluasi mengenai pemahaman siswa terhadap materi yang sudah dipelajarai. Sesuai dengan tujuan renshuu mondai, kegiatan ini digunakan siswa untuk memeriksa pencapaian target pengetahuan dan keterampilan dari materi yang telah dipelajari pada bab ini. Bagian ini bisa juga dijadikan pekerjaan rumah, namun diharapkan bagian ini juga diberi umpan balik (feedback) (Lusiana dkk, 2017).

\section{Kendala Dan Cara Mengatasi Kendala Penerapan Buku Ajar Nihongo Kirakira}

Penerapan buku ajar Nihongo Kirakira oleh guru mengalami beberapa kendala. kendala tersebut yaitu, kendala pada pelaksanaan kegiatan kakimashou dan kiiteimashou. Pada kegiatan kakimashou siswa belum menghafal huruf hiragana dan katakana dengan baik, sehingga siswa berulangkali bertanya pada guru mengenai cara penulisan huruf. Kemudian pada kegiatan kiiteimashou, audio yang tersedia pada power point tidak mengeluarkan suara. Selain mengalami kendala pada pelaksanaan kegiatan guru juga mengalami kendala pada media LCD proyektor yang rusak. Kendala lainnya yang dialami guru yaitu waktu yang kurang sehingga tidak semua kegiatan pembelajaran Nihongo Kirakira dilaksanakan guru di kelas X BB. Siswa yang tidak mendengarkan penjelasan guru serta ribut di dalam kelas juga menjadi kendala pada penerapan buku ajar Nihongo Kirakira oleh guru.

Guru mengatasi kendala penerapan buku ajar Nihongo Kirakira dengan cara memberikan latihan menulis dan menjelaskan kembali huruf-huruf yang sudah dilupakan siswa pada kegiatan kakimashou. Kemudian pada kegiatan kiite imashou guru mengunduh audio pada laman yang menyediakan audio Nihongo Kirakira. Selanjudnya kendala media LCD proyektor yang rusak diatasi guru dengan cara meminta siswa meminjam LCD di ruangan guru, selain itu guru juga memindahkan ruang kelas siswa ke kelas yang memiliki fasilitas lengkap. Kendala waktu yang kurang diatasi guru dengan cara memilih kegiatan-kegiatan pembelajaran Nihongo Kirakira yang penting. Kemudian kendala siswa yang ribut diatasi guru dengan cara menegur siswa dengan tegas dan memberi wejangan kepada siswa mengenai pentingnya belajar dan mendengarkan penjelasan guru dengan baik. 


\section{Simpulan dan Saran}

Berdasarkan hasil penelitian dan pembahasan mengenai penerapan buku ajar Nihongko Kirakira oleh guru bahasa Jepang di SMA Negeri 4 Singaraja tahun ajaran 2018/2019 dapat disimpulkan bahwa penerapan buku ajar Nihongo Kirakira oleh guru dilaksanakan sesuai dengan pedoman penggunaan buku ajar Nihongo Kirakira. Guru melaksanakan keseluruhan kegiatan pembelajaran Nihongo Kirakira. Namun pada kelas X BB guru tidak melaksanakan kegiatan Proyek (wawancara, survei, pembuatan poster, dsb) dan penilaian diri. Penerapan buku ajar Nihongo Kirakira oleh guru mengalami beberapa kendala diantaranya pada saat melaksanakan kegiatan kakimashou dan kiiteimashou. Kendala dalam menggunakan media pembelajaran, waktu yang kurang dan kendalam dalam pengelolaan kelas. Cara guru mengatasi kendala tersebut yaitu dengan memberikan latihan menulis, mengunduh audio pada laman http//erlangga.co.id/bahan-ajar-untuk-guru/cd-pembelajaran.html, memilih kegiatan pembelajaran yang penting dan menegur siswa yang ribut secara tegas serta memberi wejangan pada siswa yang ribut.

Berdasarkan temuan-temuan yang diperoleh dalam penelitian ini, saran yang dapat disampaikan yaitu penggunaan buku ajar yang sesuai dengan kegiatan dan kegiatankegiatan pembelajaran Nihongo Kirakira dapat dipertahankan dan digunakan lebih maksimalkan kembali sehingga semua kegiatan pembelajaran Nihongo Kirakira dapat terlaksana dengan baik. Guru mengalami kendala dalam menggunakan media LCD proyektor namun masalah tersebut dapat diatasi guru. Permasalahan media rusak yang mengakibatkan terganggunya fokus siswa tentu akan sangat mengganggu proses pembelajaran. LCD yang rusak disebabkan penggunaan yang kurang baik tersebut harus diatasi dengan baik. Perlunya peningkatan terhadap penelitian mengenai penerapan buku ajar Nihongo Kirakira disekolah yang berbeda dan telah menggunakan buku ajar Nihongo Kirakira di sekolah lainnya.

\section{Daftar Pustaka}

Kemendikbud. 2014. "Penetapan Satuan Pendidikan Pelaksanaan Kurikulum 2013". Tersedia pada: http://psmk.kemendikbud.go.id//1620/revisi-sk-tentang-penetapan-satuanpendidikan-pelaksanaan-kurikulum-2013. (diakses pada 29 November 2018, pukul 13.00 PM).

Fadlilah, M. 2014. Implementasi kurikulum 2013 Dalam Pembelajaran SD/MI, SMP/MTs, \& SMA/MA. Yogyakarta: PT Ar-ruzz media.

The Japan Foundation. (2017). “Nihongo Kirakira Bahasa Jepang”. Tersedia pada :http://erlangga.co.id/katalog/produk-terbaru/9427-nihongo-kirakira-bahasa-jepanguntuk-sma-kelas-x.html. (diakses pada 28 November 2018, pukul 13.00 PM).

Lusfita, dkk. 2018. "analisis kemampuan berbicara bahasa Jepang melalui teknik role play dalam buku ajar Nihongo Kirakira bab 1314 dan 1 pada siswa kelas XI bahasa MA Negeri 1 Mojokerto". Jurnal mahasiswa unesa, Vol. 6, No 1. Tersedia pada :: https://jurnalmahasiswa.unesa.ac.id/index.php/kejepangan-unesa/article/view/26126. (diakses pada 29 November 2018, pukul 13.00 PM).

Megatara, dkk. (2017). "Analisis Penggunaan Buku Ajar Nihongo Kirakira Berbasis Kurikulum 2013 Di SMA Negeri 3 Singaraja”. Jurnal mahasiswa Undiksha, Vol. 8, No 2. Tersedia pada : https://ejournal.undiksha.ac.id/index.php/JJPBJ/article/view/14998. (diakses pada 22 November 2018, pukul 11.00 PM) 